\title{
OPTIMIZATION OF SYNTHESIS CONDITIONS OF MERCURY SELENIDE THIN FILMS
}

\author{
Martyn Sozanskyi ${ }^{1},{ }^{凶}$, Vitalii Stadnik $^{1}$, Pavlo Shapoval $^{1}$, Iosyp Yatchyshyn$^{1}$, \\ Ruslana Guminilovych ${ }^{1}$, Stepan Shapoval ${ }^{2}$
}

https://doi.org/10.23939/chcht14.03.290

\begin{abstract}
The mercury selenide (HgSe) films were obtained on glass substrates via the chemical deposition method. The aqueous solutions of mercury(II) nitrate, sodium thiosulfate, sodium selenosulfate and tri-sodium citrate were used. X-ray and elemental analysis of the film sample were made. The effect of initial reagents concentration, synthesis duration and temperature on the mass of $\mathrm{HgSe}$ films was investigated and coatings thickness was calculated. The optical and morphological properties of $\mathrm{HgSe}$ films were examined. The deposition mechanism is discussed.
\end{abstract}

Keywords: mercury selenide, thin films, chemical deposition, optical properties, morphology analysis, growth mechanism.

\section{Introduction}

Mercury selenide (HgSe) is one of the least-studied of $\mathrm{A}^{\mathrm{II}} \mathrm{B}^{\mathrm{VI}}$ group thin films materials. Mercury chalcogenides can be used in IR detectors, ultrasonic transducers, catalysts, electrostatic reflective materials and solar cells due to their unique properties [1-3]. Development of simple and reproducible technique for the synthesis of mercury selenide films is an actual task. Technologically convenient way of obtaining these films is a chemical deposition [3-4]. The optimization of this process has been made for zinc and cadmium chalcogenides [5-7]. It is based on determination of metal content by anodic stripping voltammetry in a water solution, prepared by dissolving thin films [8-9]. In case of $\mathrm{HgSe}$ films it is convenient to use measurements of coatings mass changes, since mercury selenide is difficult to dissolve in water solutions.

\footnotetext{
${ }^{1}$ Department of Physical, Analytical and General Chemistry, Lviv Polytechnic National University,

12, S. Bandery St., 79013 Lviv, Ukraine

${ }^{2}$ Department of Heat and Gas Supply and Ventilation, Lviv Polytechnic National University,

12, S. Bandery St., 79013 Lviv, Ukraine

martyn.a.sozanskyi@lpnu.ua

(c) Sozanskyi M., Stadnik V., Shapoval P., Yatchyshyn I., Guminilovych R., Shapoval S., 2020
}

Previously in our research [10-11], the HgSe films were synthesized using three complexing agents: potassium thiocyanate $(\mathrm{KSCN})$, potassium iodide $(\mathrm{KI})$ and sodium thiosulfate $\left(\mathrm{Na}_{2} \mathrm{~S}_{2} \mathrm{O}_{3}\right)$. The best results were obtained with using $\mathrm{Na}_{2} \mathrm{~S}_{2} \mathrm{O}_{3}$. In the case of KSCN use the $\mathrm{HgSe}$ films surface was not solid and consisted of the spherical particles. With the use of $\mathrm{KI}$, the ternary compound of mercury iodide-selenide $\left(\mathrm{Hg}_{3} \mathrm{I}_{2} \mathrm{Se}_{2}\right)$ was found as a by-product. Cyanides, which give good results on complexation precious metals [12], are not used because of their toxicity.

The aim of our work was to carry out complex studies of effect of initial reagents concentration, synthesis duration and temperature on the mass of synthesized $\mathrm{HgSe}$ semiconductor films. Based on previous research, the $\mathrm{Na}_{2} \mathrm{~S}_{2} \mathrm{O}_{3}$ was used as the best complexing agent for $\mathrm{Hg}^{2+}$ [10]. An analysis of the obtained experimental results would allow to get more favourable conditions for $\mathrm{HgSe}$ films synthesis. In addition, it is necessary to perform such studies as $\mathrm{pH}$ measurements of working solutions, thickness calculation, analysis of phase composition, optical properties, morphology and to propose the deposition mechanism of investigated coatings. This is an actual task of thin-film technologies, especially for least-studied HgSe films.

\section{Experimental}

\subsection{Materials}

Chemical deposition of $\mathrm{HgSe}$ films was carried out on preliminarily cleaned square shape glass substrates with $64.80 \mathrm{~cm}^{2}$ of total area. For this purpose, the working solutions were prepared by successive adding of freshly prepared aqueous solutions of the mercury salt, $\mathrm{pH}$ regulator, complexing agent, chalcogenizing agent and distilled water.

The composition of the working solutions was as follows: $0.0025-0.015 \mathrm{M}$ mercury(II) nitrate $\left(\mathrm{Hg}\left(\mathrm{NO}_{3}\right)_{2}\right)$; 0.025-0.3 M trisodium citrate $\left(\mathrm{Na}_{3} \mathrm{C}_{6} \mathrm{H}_{5} \mathrm{O}_{7}\right)$, as a $\mathrm{pH}$ regulator; $0.1-2.0 \mathrm{M}$ sodium thiosulfate $\left(\mathrm{Na}_{2} \mathrm{~S}_{2} \mathrm{O}_{3}\right)$, as a complexing agent for $\mathrm{Hg}^{2+}$ and $0.0025-0.025 \mathrm{M}$ sodium selenosulfate $\left(\mathrm{Na}_{2} \mathrm{SeSO}_{3}\right)$, as a chalcogenizing reagent. 
The volume of each prepared solution was $250 \mathrm{ml}$. The synthesis was made in a glass bath for 20-220 min at the temperatures of $273-313 \mathrm{~K}$. After this, the substrates were removed, washed with distilled water and dried in the air. The films samples were dark-brown in color. Their adhesion to the glass substrates was weak. The films were easily removed after applying small mechanical efforts.

\subsection{Analysis}

Experimental arrays of intensities and angles of reflection of the test samples were obtained on a DRON3.0 X-ray diffractometer $\left(\mathrm{CuK}^{-}\right.$radiation). Preliminary processing of the experimental diffraction arrays in order to identify the phases was carried out using a PowderCell program [13].

The films optical transmission spectra were recorded on a Xion 500 «Dr. Lange» spectrophotometer in the $340-900 \mathrm{~nm}$ wavelength range. The accuracy of the optical transmission detection was $\pm 0.5 \%$.

Investigation of the films surface morphology was performed on Atomic Force Microscope (AFM) MultiMode Nanoscope IIIa (Bruker) in a tapping mode using Super Sharp Silicon tips SSS-NCLR (Nanosensors) with a typical spring constant $k=33 \mathrm{~N} / \mathrm{m}$ and resonance frequency around $180 \mathrm{kHz}$.

Elemental analysis of $\mathrm{HgSe}$ film was carried out on X-ray fluorescence (XRF) spectrometer ElvaX Light SDD (Elvatech).

The $\mathrm{pH}$ value of the working solutions was measured with a pH-150 MI pH-meter, with a glass combined electrode.

The semiempirical method PM6 was used for the modelling of the possible way of chemical reaction of the mercury selenide formation. All quantum-chemical calculations were carried out in the MOPAC 2016 software package [14] and graphical interface Winmostar [15].

In order to optimize the synthesis process, the gravimetric measurements were carried out. The mass of deposited $\mathrm{HgSe}$ films were recalculated to the unit of the substrate area. For this purpose, the differences of substrates mass before and after deposition have been measured and the differences in mass were calculated. The weighing of the samples was carried out with the use of Radwag AS 220.R2 analytical weight (accuracy $0.0002 \mathrm{~g}$ ) depending on the concentrations of initial reagents in the working solution, the synthesis duration and temperature.

To conduct the research on optimization of $\mathrm{Hg}$ containing salt initial concentration for synthesis of $\mathrm{HgSe}$ films, the working solutions were prepared with $0.5 \mathrm{M}$ sodium thiosulfate, $0.01 \mathrm{M}$ sodium selenosulfate and $0.1 \mathrm{M}$ trisodium citrate. Concentration of $\mathrm{Hg}\left(\mathrm{NO}_{3}\right)_{2}$ varied from 0.0025 to $0.015 \mathrm{M}$. The synthesis duration was $180 \mathrm{~min}$, and the temperature was $283 \mathrm{~K}$.
To conduct the research on optimization of sodium thiosulfate initial concentration, the working solutions were prepared with $0.01 \mathrm{M}$ mercury(II) nitrate, $0.01 \mathrm{M}$ sodium selenosulfate and $0.1 \mathrm{M}$ trisodium citrate. Concentration of $\mathrm{Na}_{2} \mathrm{~S}_{2} \mathrm{O}_{3}$ varied from 0.12 to $2.0 \mathrm{M}$. The synthesis duration was $180 \mathrm{~min}$, and the temperature was $283 \mathrm{~K}$.

To conduct the research on optimization of sodium selenosulfate initial concentration, the working solutions were prepared with $0.01 \mathrm{M}$ mercury(II) nitrate, $0.5 \mathrm{M}$ sodium thiosulfate and $0.1 \mathrm{M}$ trisodium citrate. Concentration of $\mathrm{Na}_{2} \mathrm{SeSO}_{3}$ varied from 0.0025 to $0.025 \mathrm{M}$. The synthesis duration was $180 \mathrm{~min}$, and the temperature was $283 \mathrm{~K}$.

To conduct the research on optimization of trisodium citrate initial concentration, the working solutions were prepared with $0.01 \mathrm{M}$ mercury(II) nitrate, $0.5 \mathrm{M}$ sodium thiosulfate and $0.01 \mathrm{M}$ sodium selenosulfate. Concentration of $\mathrm{Na}_{3} \mathrm{C}_{6} \mathrm{H}_{5} \mathrm{O}_{7}$ varied from 0.025 to $0.3 \mathrm{M}$. The synthesis duration was $180 \mathrm{~min}$, and the temperature was $283 \mathrm{~K}$.

To conduct the research on optimization of synthesis duration, the working solutions were prepared with $0.01 \mathrm{M}$ mercury(II) nitrate, $0.5 \mathrm{M}$ sodium thiosulfate, $0.01 \mathrm{M}$ sodium selenosulfate and $0.1 \mathrm{M}$ trisodium citrate. The synthesis temperature was $283 \mathrm{~K}$. The duration of process varied from 20 to $220 \mathrm{~min}$.

To conduct the research on optimization of synthesis temperature the working solutions were prepared with $0.01 \mathrm{M}$ mercury(II) nitrate, $0.5 \mathrm{M}$ sodium thiosulfate, $0.01 \mathrm{M}$ sodium selenosulfate and $0.1 \mathrm{M}$ trisodium citrate. The synthesis duration was $180 \mathrm{~min}$. The temperature of process varied from 273 to $313 \mathrm{~K}$.

The calculation of HgSe films thicknesses according to the measured mass of coatings was carried out based on the following considerations. $\left(\mathrm{cm}^{3}\right)$ is:

i) The volume of the deposited film on the substrate

$$
V=\frac{\Delta m}{\rho}=\frac{m_{2}-m_{1}}{\rho}
$$

where $\Delta m$ is the film mass, g; $m_{1}$ and $m_{2}$ are the masses of substrate before and after synthesis, respectively, g; $\rho$ is the compound density, $\mathrm{g} / \mathrm{cm}^{3}\left(8.26 \mathrm{~g} / \mathrm{cm}^{3}\right.$ for $\left.\mathrm{HgSe}\right)$.

ii) Since the synthesis was performed on substrates of square shape, it is possible to assume that the coatings had approximately the shape of the parallelepiped and is expressed by the formula:

$$
V=S \cdot d
$$

where $S$ is the surface area of the substrate, $\mathrm{cm}^{2} ; d$ is the height (thickness) of the film, $\mathrm{cm}$.

iii) Equating (3) and (4) we can derive a formula for calculating the average thickness of $\mathrm{HgSe}$ films from the mass of coating:

$$
d=\frac{m_{2}-m_{1}}{S \cdot \rho}
$$




\section{Results and Discussion}

By mass measuring of deposited HgSe films, the dependences of their changes on the synthesis conditions were constructed. According to Eq. (3), the masses were recalculated into thicknesses. The research results are presented in Fig. 1.

The obtained data (Fig. 1a) show that weight of $\mathrm{HgSe}$ films increases practical linearly at $\mathrm{C}\left(\mathrm{Hg}\left(\mathrm{NO}_{3}\right)_{2}\right) \leq 0.01 \mathrm{M}$. At this, the determined $\mathrm{pH}$ of the working solutions before the addition of $\mathrm{Na}_{2} \mathrm{SeSO}_{3}$ was greater than 7 and they were colorless for a long time, without signs of turbidity. At $C\left(\mathrm{Hg}\left(\mathrm{NO}_{3}\right)_{2}\right) \geq 0.01 \mathrm{M}$ the $\mathrm{pH}$ of the working solution was less than 7. When $C\left(\mathrm{Hg}\left(\mathrm{NO}_{3}\right)_{2}\right)=0.0125 \mathrm{M}$, a slight turbidity of the solution was observed in a light brown color before adding $\mathrm{Na}_{2} \mathrm{SeSO}_{3}$. That was due to $\mathrm{Na}_{2} \mathrm{~S}_{2} \mathrm{O}_{3}$ decomposition with the formation of sulfur and its following transformation to HgS. At $C\left(\mathrm{Hg}\left(\mathrm{NO}_{3}\right)_{2}\right)=0.015 \mathrm{M}$ the huge amount of $\mathrm{HgS}$ was observed to be formed due to the proceeding of the process above to a greater extent at a more acidic $\mathrm{pH}$. In this case the amount of free $\mathrm{Hg}^{2+}$ ions is low. This explains the decrease of the HgSe mass in this area. Thus, the optimized value of mercury salt concentration is $0.01 \mathrm{M}$.

The influence of sodium thiosulfate concentration on the mass of $\mathrm{HgSe}$ films (Fig. 1b) has an extremum character. At small concentration of $\mathrm{Na}_{2} \mathrm{~S}_{2} \mathrm{O}_{3}(\leq 0.5 \mathrm{M})$, the mass increasing of the deposited film was observed. At $C\left(\mathrm{Na}_{2} \mathrm{~S}_{2} \mathrm{O}_{3}\right)>0.5 \mathrm{M}$ the weight of $\mathrm{HgSe}$ coatings decreases as a result of increasing the working solution density. Thus, the optimized value of sodium thiosulfate concentration was $0.5 \mathrm{M}$.

In the study on dependence of sodium selenosulfate concentration change on the mass of $\mathrm{HgSe}$ films (Fig. 1c), it was found that in the range of $C\left(\mathrm{Na}_{2} \mathrm{SeSO}_{3}\right)=$ $=0.0025-0.01 \mathrm{M}$ the dependence character is close to linear, and after that the mass of $\mathrm{HgSe}$ gradually decreases. It was because the reaction product had formed more in the form of a precipitate and not as a film. Thus, the optimized value of sodium selenosulfate concentration is $0.01 \mathrm{M}$.

With the increase in synthesis duration from 20 to $180 \mathrm{~min}$ (Fig. 1e) the mass of $\mathrm{HgSe}$ films increases almost linearly. At longer synthesis period, the mass value practically does not change. Thus, the optimized value of the synthesis duration is $180 \mathrm{~min}$.

The temperature dependence of $\mathrm{HgSe}$ films mass (Fig. 1f) has the extremum character. In the temperature range of $283-313 \mathrm{~K}$, the mass of coatings decreases practically linearly, because at the higher temperatures the reaction product had formed in greater extent in the form of a precipitate but not as a film. At $273 \mathrm{~K}$, the film mass is less than at $283 \mathrm{~K}$, since it needs more time to end the synthesis process, which is inexpedient. Thus, the optimized temperature is $283 \mathrm{~K}$.

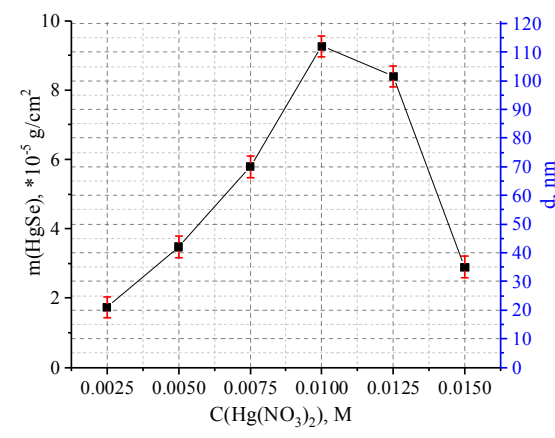

a)

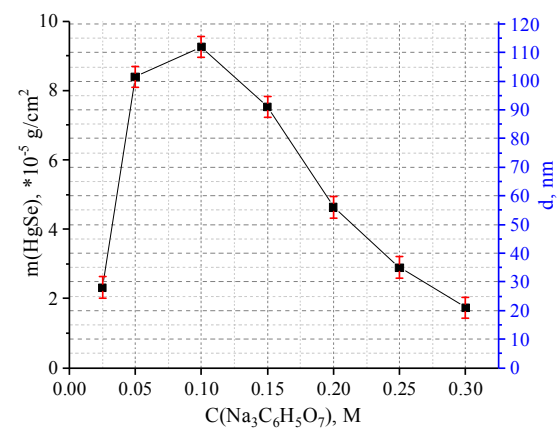

d)

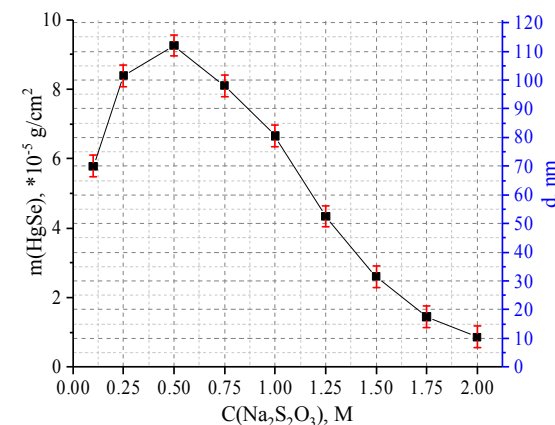

b)

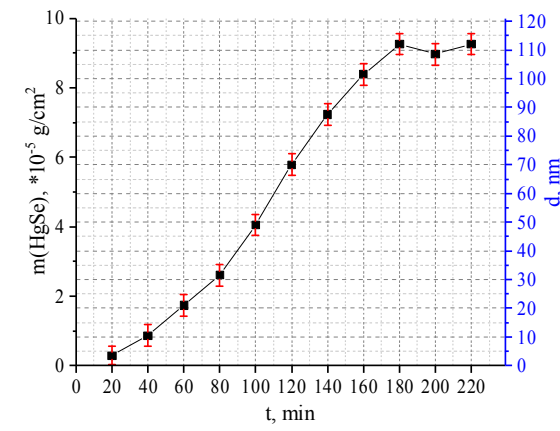

e)

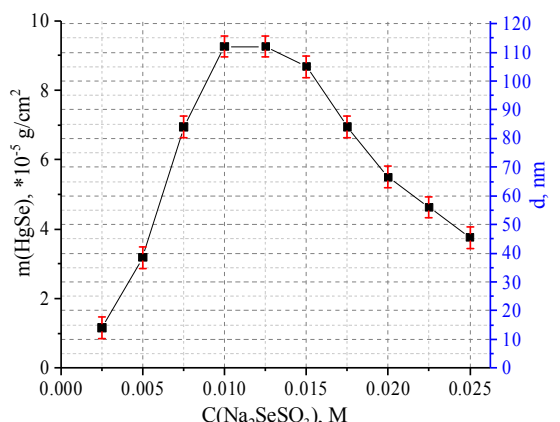

c)

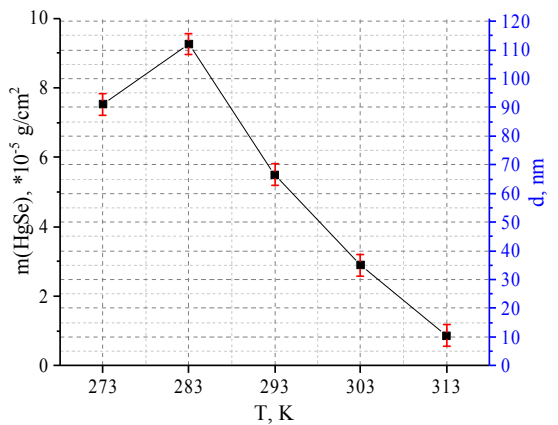

f)

Fig 1. Dependences of films mass changes of HgSe per unit of substrate area on the concentration of $\mathrm{Hg}$-containing salt (a), $\mathrm{Na}_{2} \mathrm{~S}_{2} \mathrm{O}_{3}(\mathrm{~b}), \mathrm{Na}_{2} \mathrm{SeSO}_{3}$ (c), $\mathrm{Na}_{3} \mathrm{C}_{6} \mathrm{H}_{5} \mathrm{O}_{7}$ (d). Dependences of films mass on synthesis duration (e) and temperature (f) 
When studying the influence of trisodium citrate concentration on HgSe films mass (Fig. 1d), the parallel measurements of working solutions $\mathrm{pH}$ values were carried out at a sequential addition of reagents to the solutions with different concentrations of $\mathrm{Na}_{3} \mathrm{C}_{6} \mathrm{H}_{5} \mathrm{O}_{7}$ (Table). In the case of $C\left(\mathrm{Na}_{3} \mathrm{C}_{6} \mathrm{H}_{5} \mathrm{O}_{7}\right)=0.025 \mathrm{M}$, the solution before addition of $\mathrm{Na}_{2} \mathrm{~S}_{2} \mathrm{O}_{3}$ is slightly acidic and after addition of sodium thiosulfate, $\mathrm{pH}$ remained in the acid region. At this, significant amount of $\mathrm{HgS}$ formation was observed, due to the decomposition of $\mathrm{Na}_{2} \mathrm{~S}_{2} \mathrm{O}_{3}$. In that case, the mass of deposited $\mathrm{HgSe}$ film on the substrate after the addition of $\mathrm{Na}_{2} \mathrm{SeSO}_{3}$ was small, since most of the mercury ions had already been consumed. In the case of $C\left(\mathrm{Na}_{3} \mathrm{C}_{6} \mathrm{H}_{5} \mathrm{O}_{7}\right)=0.05 \mathrm{M}$, the solution before adding $\mathrm{Na}_{2} \mathrm{~S}_{2} \mathrm{O}_{3}$ is weakly acid, after adding it - slightly alkaline. At this time the solution becomes brown and later the small amount of $\mathrm{HgS}$ precipitate is formed. As a result, the mass of deposited $\mathrm{HgSe}$ on substrates at $\mathrm{Na}_{3} \mathrm{C}_{6} \mathrm{H}_{5} \mathrm{O}_{7}$ concentration of $0.05 \mathrm{M}$ is greater than that at $0.025 \mathrm{M}$. Next, starting from $C\left(\mathrm{Na}_{3} \mathrm{C}_{6} \mathrm{H}_{5} \mathrm{O}_{7}\right)=0.10 \mathrm{M}$, the solutions were slightly alkaline, stable (transparent and colourless), decomposition of $\mathrm{Na}_{2} \mathrm{~S}_{2} \mathrm{O}_{3}$ was not observed. In the $\mathrm{Na}_{3} \mathrm{C}_{6} \mathrm{H}_{5} \mathrm{O}_{7}$ concentration range from 0.10 to $0.30 \mathrm{M}$, the mass of $\mathrm{HgSe}$ films decreases practically linearly. Probably this is due to the increase of the working solution density. Finally, when $\mathrm{Na}_{2} \mathrm{SeSO}_{3}$ was added in all of working solutions, the hydrogen index was within 8.51-8.60 (the start of deposition). At the end of deposition, $\mathrm{pH}$ decreased to 8.34-8.43. Thus, from the provided measurements, the optimized value of trisodium citrate concentration is $0.10 \mathrm{M}$.

So, the optimum conditions for deposition of $\mathrm{HgSe}$ films are: concentrations of mercury salt, trisodium citrate, sodium thiosulfate and sodium selenosulfate in the working solution $0.01 \mathrm{M}, 0.1 \mathrm{M}, 0.5 \mathrm{M}$ and $0.01 \mathrm{M}$, respectively; synthesis duration $180 \mathrm{~min}$, temperature $283 \mathrm{~K}$. Under these conditions the biggest thickness of $\mathrm{HgSe}$ films was reached, which was $112 \mathrm{~nm}$.
The X-ray phase analysis (Fig. 2) of HgSe films, obtained under optimum conditions, has been made. It was established that the coating is a single-phase one and contains $\mathrm{HgSe}$ in the cubic (zincblende) modification.

The optical transmission $T(\lambda)$ and absorption spectra (dependences in $(\alpha \cdot h v)^{2}=f(h v)$ coordinates) of HgSe films, obtained at synthesis durations of 30-210 min are shown on Figs. 3 and 4, respectively (the other synthesis parameters were equal to optimum ones). The minimum light transmission $\left(T_{\min }\right)$ in the investigated range of wavelength is located at $340 \mathrm{~nm}$ for all samples. A jump of the light transmission can be seen at $\sim 450 \mathrm{~nm}$. The maximum light transmission $\left(T_{\max }\right)$ in the investigated range of wavelength for all samples is located at $900 \mathrm{~nm}$. In the investigated region of synthesis duration, the $T_{\min }$ and $T_{\max }$ decreases from $\sim 72$ to $0.3 \%$ and from $\sim 94$ to $45 \%$, respectively. The values of optical band gap (defined as the intersection point of the tangent to linear section of the dependence $(\alpha \cdot h v)^{2}=f(h v)$ and the $x$-axis) decrease from 2.47 to $1.39 \mathrm{eV}$ with the increase of the synthesis duration (Fig. 4). These optical band gap values are close to the results obtained in [16-18].

AFM studies of the surface morphology (Fig. 5) of HgSe films, obtained at different synthesis duration (the other parameters were equal to optimum ones), show that coating is solid and homogeneous. It can be seen that at $100 \mathrm{~min} \mathrm{HgSe}$ film surface is packed of irregular shape particles of approximately $65 \pm 12 \mathrm{~nm}$ in size. At $180 \mathrm{~min}$, the coating surface consists of aggregates of $152 \pm 17 \mathrm{~nm}$ in size. It can be seen that they are formed by smaller particles of 15-60 nm. This could mean that they stick together and deposit on the surface during the film synthesis, so the aggregation process of smaller particles has a huge impact on its morphology.

According to the results of elemental analysis (Fig. 6), the HgSe films have a practically stoichiometric composition with a slight excess of selenium atoms.

Table

The measured $\mathrm{pH}$ values of the working solutions with various concentrations of $\mathrm{Na}_{3} \mathrm{C}_{6} \mathrm{H}_{5} \mathrm{O}_{7}$

\begin{tabular}{|c|c|c|c|c|}
\hline \multirow[b]{2}{*}{$\mathrm{C}\left(\mathrm{Na}_{3} \mathrm{C}_{6} \mathrm{H}_{5} \mathrm{O}_{7}\right), \mathrm{M}$} & \multicolumn{4}{|c|}{ The $\mathrm{pH}$ of the solution, which contained: } \\
\hline & $\begin{array}{c}\mathrm{C}\left(\mathrm{Na}_{3} \mathrm{C}_{6} \mathrm{H}_{5} \mathrm{O}_{7}\right)^{+} \\
+0.01 \mathrm{M} \mathrm{Hg}\left(\mathrm{NO}_{3}\right)_{2}\end{array}$ & $\begin{array}{c}\mathrm{C}\left(\mathrm{Na}_{3} \mathrm{C}_{6} \mathrm{H}_{5} \mathrm{O}_{7}\right)+ \\
+0.01 \mathrm{M} \mathrm{Hg}\left(\mathrm{NO}_{3}\right)_{2}+ \\
+0.5 \mathrm{M} \mathrm{Na}_{2} \mathrm{~S}_{2} \mathrm{O}_{3}\end{array}$ & $\begin{array}{c}\mathrm{C}\left(\mathrm{Na}_{3} \mathrm{C}_{6} \mathrm{H}_{5} \mathrm{O}_{7}\right)+ \\
\left.+0.01 \mathrm{M} \mathrm{Hg} \mathrm{NO}_{3}\right)_{2}+ \\
+0.5 \mathrm{M} \mathrm{Na}_{2} \mathrm{~S}_{2} \mathrm{O}_{3}+ \\
+0.01 \mathrm{M} \mathrm{Na}_{2} \mathrm{SeSO}_{3} \\
\text { (at the start of deposition) }\end{array}$ & $\begin{array}{c}\mathrm{C}\left(\mathrm{Na}_{3} \mathrm{C}_{6} \mathrm{H}_{5} \mathrm{O}_{7}\right)+ \\
\left.+0.01 \mathrm{M} \mathrm{Hg} \mathrm{NO}_{3}\right)_{2}+ \\
+0.5 \mathrm{M} \mathrm{Na}_{2} \mathrm{~S}_{2} \mathrm{O}_{3}+ \\
+0.01 \mathrm{M} \mathrm{Na}_{2} \mathrm{SeSO}_{3} \\
\text { (at the end of deposition) }\end{array}$ \\
\hline 0.025 & 6.38 & 6.72 & 8.51 & 8.34 \\
\hline 0.05 & 6.77 & 7.63 & 8.56 & 8.37 \\
\hline 0.10 & 7.03 & 7.83 & 8.60 & 8.42 \\
\hline 0.15 & 7.18 & 7.91 & 8.59 & 8.41 \\
\hline 0.20 & 7.31 & 7.98 & 8.57 & 8.42 \\
\hline 0.25 & 7.37 & 8.00 & 8.59 & 8.43 \\
\hline 0.30 & 7.42 & 8.01 & 8.58 & 8.40 \\
\hline
\end{tabular}




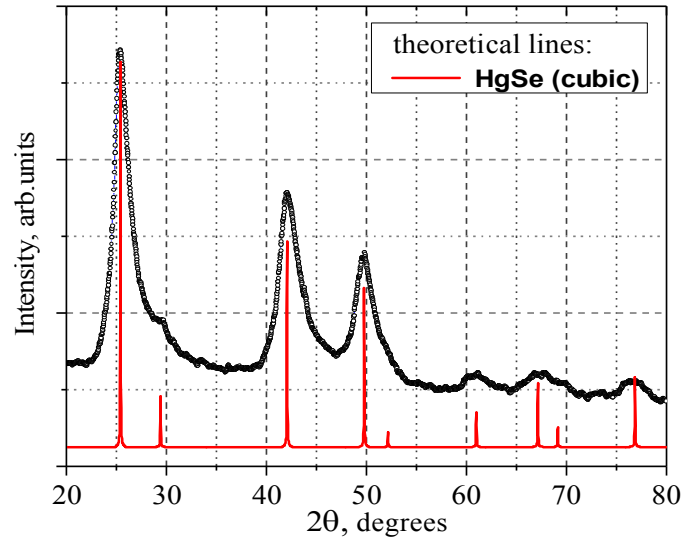

Fig. 2. The X-ray diffraction pattern of HgSe film, obtained under optimum conditions and its comparison with the lines of theoretical diffraction pattern of $\mathrm{HgSe}$

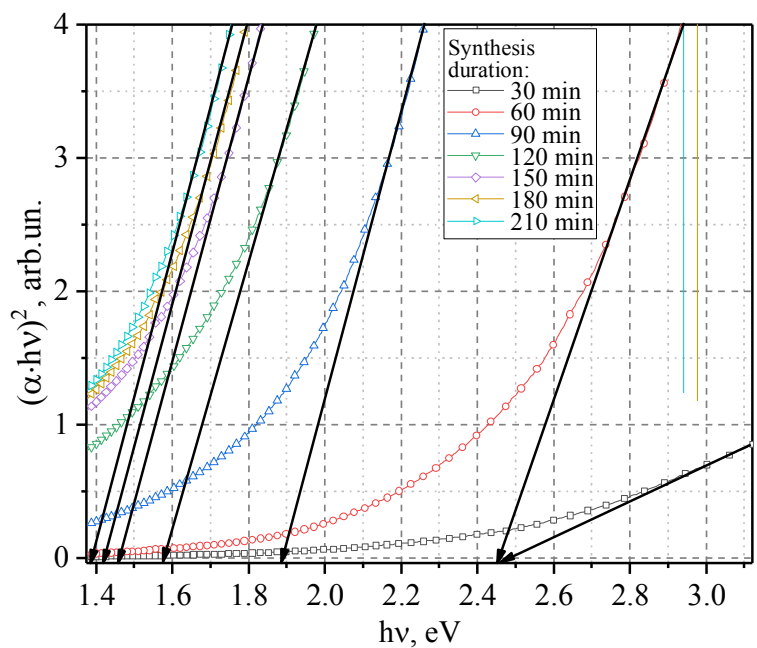

$120.0 \mathrm{~nm}$

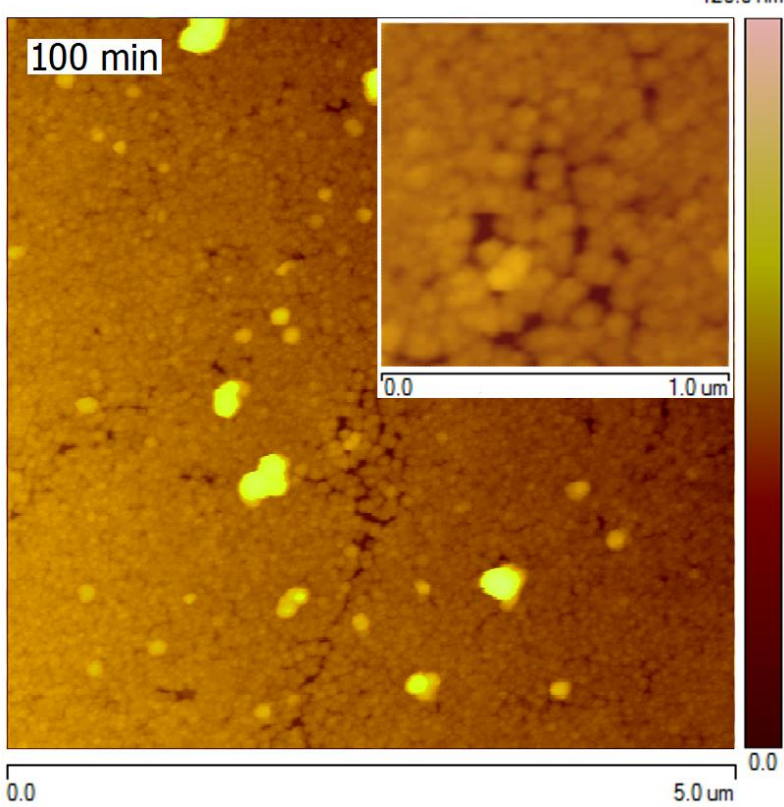

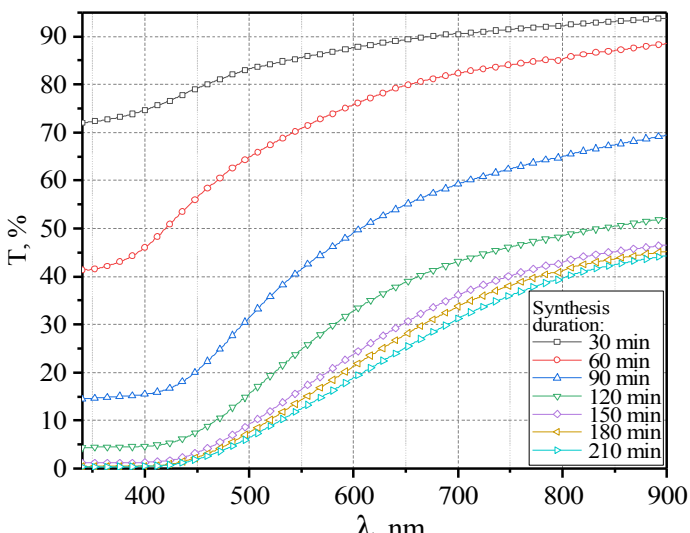

Fig. 3. Spectral dependences of optical transmission $(T, \%)$ of $\mathrm{HgSe}$ films, obtained at different synthesis durations

Fig. 4. Dependence of $(\alpha \cdot h v)^{2}=f(h v)$ (where $\alpha$ - optical absorption coefficient) of $\mathrm{HgSe}$ film, obtained at different synthesis durations

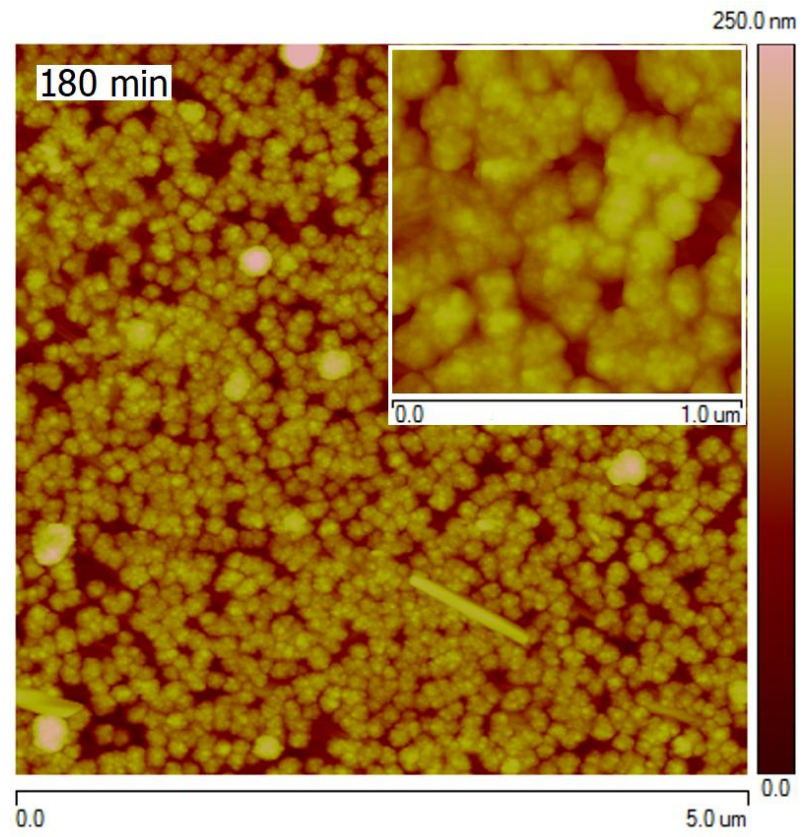

Fig. 5. AFM images of $5 \times 5 \mu \mathrm{m}$ and $1 \times 1 \mu \mathrm{m}$ (insets) size of $\mathrm{HgSe}$ films, obtained at different synthesis durations 


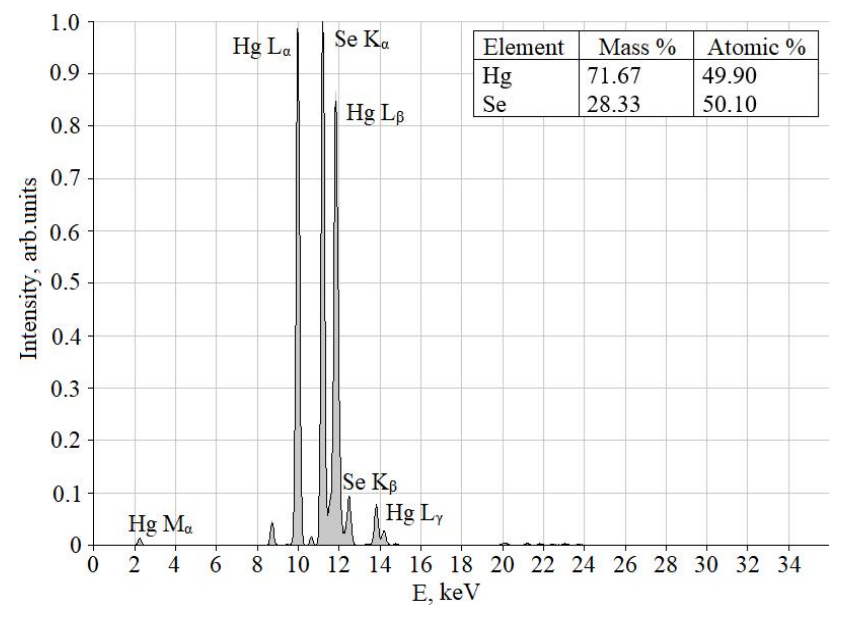

Fig. 6. XRF spectra of HgSe film and results of elemental analysis

The quantum-chemical modelling of possible and most profitable way of chemical reaction of $\mathrm{HgSe}$ formation from the aqueous solution with thiosulfate was made. The formation of $\left[\mathrm{Hg}\left(\mathrm{S}_{2} \mathrm{O}_{3}\right)_{4}\right]^{6-}$ soluble complex occurs after mixing of the mercury salt and sodium thiosulfate solutions. A minor amount of trisodium citrate is added to the solution to provide the alkaline medium and prevent sodium thiosulfate decomposition. The formed complex is changed after adding $\mathrm{Na}_{2} \mathrm{SeSO}_{3}$ to the solution. The selenosulfate-ion coordinates with a mercury atom through a selenium atom and the reactive-able intermediate complex of $\left[\mathrm{SO}_{3} \mathrm{Se} \cdots \cdot \cdot \operatorname{Hg}\left(\mathrm{S}_{2} \mathrm{O}_{3}\right)_{3}\right]^{6-}$ is formed. After that it reacts with hydroxide ions and partially decomposes to $\left[\mathrm{Se} \cdot \cdots \cdot \mathrm{Hg}\left(\mathrm{S}_{2} \mathrm{O}_{3}\right)_{3}\right]^{6-}$, sulfate ion and water. Finally, intermediate complex decomposes with the formation of mercury selenide and thiosulfate ions. Schematically, this process can be written as:

$$
\begin{gathered}
\left.\left[\mathrm{Hg}_{(} \mathrm{S}_{2} \mathrm{O}_{3}\right)_{4}\right]^{6-}+\mathrm{SeSO}_{3}^{2-} \longrightarrow\left[\mathrm{SO}_{3} \mathrm{Se} \cdots \mathrm{Hg}\left(\mathrm{S}_{2} \mathrm{O}_{3}\right)_{3}\right]^{6-}+\mathrm{S}_{2} \mathrm{O}_{3}^{2-} \\
{\left[\mathrm{SO}_{3} \mathrm{Se} \cdots \mathrm{Hg}\left(\mathrm{S}_{2} \mathrm{O}_{3}\right)_{3}\right]^{6-}+2 \mathrm{OH}^{-} \longrightarrow} \\
\longrightarrow\left[\mathrm{Se} \cdots \mathrm{Hg}\left(\mathrm{S}_{2} \mathrm{O}_{3}\right)_{3}\right]^{6-}+\mathrm{SO}_{4}^{2-}+\mathrm{H}_{2} \mathrm{O} \\
{\left[\mathrm{Se} \cdots \mathrm{Hg}\left(\mathrm{S}_{2} \mathrm{O}_{3}\right)_{3}\right]^{6-} \longrightarrow \mathrm{HgSe} \downarrow+3 \mathrm{~S}_{2} \mathrm{O}_{3}^{2-}}
\end{gathered}
$$

On the basis of surface morphology data and results from [19], the following scheme of $\mathrm{HgSe}$ film growth was proposed (Fig. 7). It begins with the formation of nuclei in the working solution and active centers on the substrate surface due to the decomposition reaction of intermediate mercury complexes. Next, the cluster particles of fractal structure are formed. The primary surface particles may also appear by forming oxygen bridges of $\mathrm{Hg}-\mathrm{O}-\mathrm{Si}$ type on the glass substrate surface. As a result of the particles Brownian motion and crystallization of reaction product, the further coagulation and growth of aggregates occur with their adsorption on the surface. This process stops after depletion of working solution (180 min of $\mathrm{HgSe}$ deposition). The destruction of $\mathrm{HgSe}$ film under small mechanical efforts indicates weakness of intermolecular bonds between the aggregates and bonds between the film and substrate surface $(\mathrm{Hg}-\mathrm{O}-\mathrm{Si})$, which prove the proposed scheme of film growth.

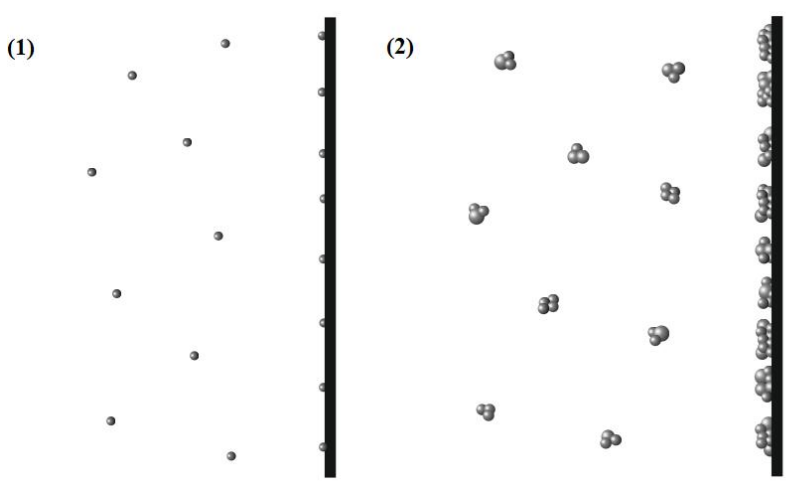

(3)

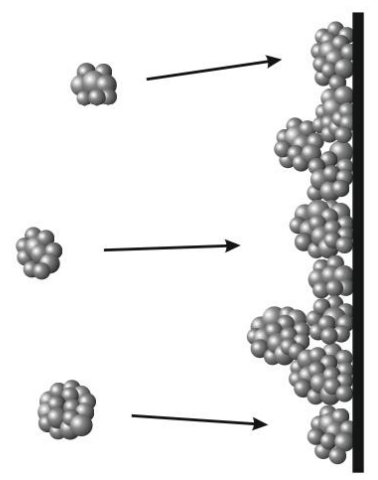

(4)

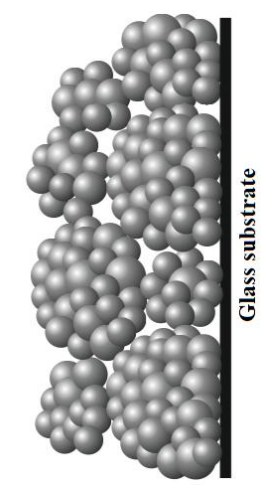

Fig. 7. Scheme of HgSe nucleation and film growth

\section{Conclusions}

In our work, an attempt was made to comprehensively consider the problems of $\mathrm{HgSe}$ films synthesis with the aim of developing common rules and approaches for controlling the process of their hydrochemical synthesis. The influence of concentrations of mercury salt, trisodium citrate, sodium thiosulfate and sodium selenosulfate in the working solution, duration and temperature of synthesis on the mass of $\mathrm{HgSe}$ films are shown. Practically, at synthesis of $\mathrm{HgSe}$ films from aqueous $\mathrm{Na}_{2} \mathrm{~S}_{2} \mathrm{O}_{3}$ solutions, it is expedient to use the following parameters of synthesis: the concentrations of mercury salt, trisodium citrate, sodium thiosulfate and sodium selenosulfate in the working solution of $0.01 \mathrm{M}, 0.1 \mathrm{M}, 0.5 \mathrm{M}$ and $0.01 \mathrm{M}$, respectively, temperature of $283 \mathrm{~K}$ and synthesis 
duration of $180 \mathrm{~min}$. The reason is that the films, synthesized under such conditions are single-phase, solid and homogeneous, the $\mathrm{HgSe}$ is formed most in the form of a coating but not a precipitate and has the highest average thickness $(\sim 112 \mathrm{~nm})$. This can be used to obtain double or multilayer heterostructures of $\mathrm{HgSe}$ with other semiconductor films.

\section{Acknowledgments}

This research is under the project "Thin Film Semiconductor Materials for Photo Sensitive Solar Cells" (State Registration No. 0117U004455).

\section{References}

[1] Bazarganipour M., Sadri M., Davar D., Salavati-Niasari M.: Polyhedron, 2011, 30, 1103.

https://doi.org/10.1016/j.poly.2011.01.023

[2] Esmaeili-Zare M., Salavati-Niasari M., Sobhani A.: Ultrason. Sonochem., 2012, 19, 1079.

https://doi.org/10.1016/j.ultsonch.2012.01.013

[3] Pawar S., Pawar B., Kim J. et al.: Curr. Appl. Phys., 2011, 11, 117. https://doi.org/10.1016/j.cap.2010.07.007

[4] Bansode S., Kapadnis R., Wagh V. et al.: Chem. Chem.

Technol., 2014, 8, 441.

[5] Sozanskyi M., Shapoval P., Chaykivska R. et al.: Visnyk Lviv. Polytech. Nats. Univ., 2016, 841, 36.

[6] Shapoval P., Sozanskyi M., Yatchyshyn I. et al.: Odes'kyi

Politechnichnyi Universytet. Pratsi., 2015, 3, 119.

https://doi.org/10.15276/opu.3.47.2015.17

[7] Shapoval P., Guminilovych R., Yatchyshyn I.: Chem. Chem. Technol., 2013, 7, 345. https://doi.org/10.23939/chcht07.03.345

[8] Shapoval P., Sozanskyi M., Yatchyshyn I. et al.: Chem. Chem. Technol., 2016, 10, 317. https://doi.org/10.23939/chcht10.03.317

[9] Shapoval P., Guminilovych R., Yatchyshyn I., Shapoval S.:

Chem. Chem. Technol., 2015, 9, 287.

https://doi.org/10.23939/chcht09.03.287
[10] Sozanskyi M., Stadnik, V., Chaykivska, R. et al.: Voprosy Khimii i Khimicheskoi Tekhnologii, 2018, 4, 69 .

[11] Sozanskyi M., Stadnik V., Chaykivska R. et al.: Chem. Chem. Technol., 2017, 11, 445. https://doi.org/10.23939/chcht1 1.04.445

[12] Kuntyi O., Shepida M., Sus L. et al.: Chem. Chem. Technol., 2018, 12, 305. https://doi.org/10.23939/chcht12.03.305

[13] Kraus W., Nolze G.: PowderCell for Windows (version 2.4). Federal Institute for Materials Research and Testing, Berlin 2000.

[14] Stewart J.: Program Package MOPAC 2016.

http://www.openmopac.net

[15] Senda N.: Program Package Winmostar (version 8.001). http://winmostar.com

[16] Pejova B., Najdoski M., Grozdanov I. et al.: J. Mater. Chem., 1999, 9, 2889. https://doi.org/10.1039/a905452i

[17] Ranga Rao A., Dutta V.: Sol. Energy Mater. Sol. Cells., 2011, 95, 1050. https://doi.org/10.1016/j.solmat.2010.10.030

[18] Howes P., Green M., Johnston C. et al.: J. Mater. Chem., 2008 , 18, 3474. https://doi.org/10.1039/b804158j

[19] Maskaeva L., Markov V., Tulenin S. et al.: Gidrokhimicheskoe Osazhdenie Tonkikh Plenok Khalkogenidov Metallov: Praktikum. Izd-vo Uralskogo Univ., Ekaterinburg 2017.

Received: April 04, 2019 / Revised: July 02, 2019 / Accepted: December 18, 2019

\section{ОПТИМІЗАЦІЯ УМОВ СИНТЕЗУ ТОНКИХ ПЛІВОК МЕРКУРІЙ СЕЛЕНІДУ}

Анотація. На скляних підкладках методом хімічного осадження отримані плівки меркурій селеніду (HgSe). Використано водні розчини меркурій(II) нітрату, натрію тіосульфату, натрію селеносульфату та тринатрій циттрату. Проведено рентгенофазовий та елементний аналіз зразка плівки. Досліджено вилив конщентрації вихідних реагентів, тривалості та температури синтезу на масу плівок $\mathrm{HgSe}$ та обчислено товщину покриттів. Досліджено оптичні та морфологічні властивості покриття $\mathrm{HgSe}$. Обговорено механізм осадження.

Ключові слова: меркурій селенід, тонкі плівки, хімічне осадження, оптичні властивості, морфологічний аналіз, механізм росту. 